\title{
Research on the Integration of Legal Education of Entrepreneurship and Professional Education for Science and Engineering Students
}

\author{
Hong-zhen $\operatorname{LIN}^{1, \text { a* }}$, Rui MA ${ }^{1}$, Jie $\mathrm{LV}^{1, \mathrm{c}}$ \\ ${ }^{1}$ School of Hengda Management, Wuhan University of Science and Technology Wuhan, China \\ 947 He Ping Street, Hubei Wuhan 430081, China \\ alinhongzhen@126.com, b1057607653@qq.com,c947833665@qq.com
}

\begin{abstract}
With the purpose of probing into the integration path between entrepreneurial legal education and professional education, this paper deeply understands and analyzes the problem of the integration of legal education of entrepreneurship and professional education for science and engineering students with the adoptation of the method of document study, case study, questionnaires and interviews. On the basis of the relationship between entrepreneurial education and professional education, this paper draws on the successful experience and enlightenment from the developed countries to carry out the entrepreneurship education. The results show that Chinese universities should change the status of legal education of entrepreneurship and professional education based on the characteristics and advantages of each university, strengthen the integration between entrepreneurial education and professional education, build a growth platform for education faculty of entrepreneurship law and gradually form an education system of entrepreneurial law with different characteristics. Moreover, improve the legal quality, knowledge and ability of college students' entrepreneurship based on the integration of funds, resources and talents.
\end{abstract}

Keywords-Entrepreneurship; Legal Education; Professional Education; Integration Education

\section{INTRODUCTION}

In recent years, the employment of college students is not only related to their families, but also a social problem. With the increase of the number of college graduates and the impact of economic slowdown, contemporary college students are in a "difficult employment" situation [1]. Faced with such a severe employment situation, the party has put forward development strategies of "improving the ability of independent innovation, building an innovative country" and "promoting employment through entrepreneurship" at the 17th national congress. In the era of industrial transformation and upgrading and innovation driven by the country, many colleges and universities have actively respond to the nation call to start promoting entrepreneurship and employment, entrepreneurship education, and some universities have incorporated entrepreneurial guidance into the teaching curriculum system. The atmosphere of entrepreneurial education is increasingly strong, but the effect is not very ideal. One of the important factors is the lack of legal education in entrepreneurial education of college students [2]. The diversity, practicality and comprehensive characteristics of entrepreneurial education make it an effective means to cultivate innovative talents. To clarify the relationship between innovation, entrepreneurship and entrepreneurship education and professional education, and to learn from the successful experience of developed countries for entrepreneurship education, the entrepreneurship education of Chinese colleges and universities should change the present "one-size-fits-all" situation, carry out the entrepreneurship education based on its own characteristics and advantages, and make a development to the whole school and long-term entrepreneurship education, strengthen the integration between entrepreneurship education and professional education, build the platform for the growth of entrepreneurship education teachers, gradually formed the distinctive entrepreneurship education system

\section{THE NECESSITY OF STRENGTHENING LEGAL EDUCATION AND PROFESSIONAL INTEGRATION}

\section{A. Helping College Students To Reduce The Legal Risk Of Entrepreneurship}

Legal risks are everywhere, but they can be minimized or within tolerable limits through reasonable precautions. To systematically guard against legal risks, the first thing is to understand relevant legal knowledge. Only when entrepreneurs fully understand the sources and characteristics of major legal risks can they effectively prevent them. Nowadays, many college students isn't aware of the legal risks involved in entrepreneurship, the survey of the blue book (2016) of the development of innovation and entrepreneurship education (In Chinese) colleges and universities shows that college students generally do not understand entrepreneurship law. Entrepreneurship itself is a complex system engineering, which objectively requires college students to have higher legal literacy and legal ability. Weak legal consciousness and insufficient legal ability are the main reasons for the failure of entrepreneurship. College students have a strong desire to learn about the relevant legal knowledge of entrepreneurship. 


\section{B. Improving The Consistency Of Theory and Practice Of University Law Education.}

The development of entrepreneurial education in China is in the ascendant. Entrepreneurial education aims to comprehensively improve the comprehensive quality of college students and cultivate qualified college students in line with the development needs of the new era. With the development of the socialist market economy and the gradual improvement of the socialist rule of law, China is in a critical period of promoting the rule of law, legal education to strengthen college students' entrepreneurship is to make students adapt to society and realize the modernization of the key factors of rule of law, strengthen the entrepreneurship law education has important practical significance. However, education is still weak in China's entrepreneurial law [3].

The important purpose of university education is to make students a deeper understanding of their world, to learn how to use their knowledge and skills to make the world a better place, make students realize self-worth while contribute to the development of the society. It is necessary for college students to combine professional knowledge, professional skills and entrepreneurial education. University education cannot be isolated from the outside world, it should always pay attention to the change of the outside world, but also lead time. Entrepreneurial education plays an important role in promoting the reform of higher education in China.

\section{Enhancing The Entrepreneurial Legal Quality Of College Students.}

Colleges and universities comply with the inevitable requirements of social development, which is an important part of implementing the ministry of education to strengthen education and cultivate high-quality talents with entrepreneurship and innovation spirit. Market economy is an economy of the rule of law, the law set the rule for economic activities, each market subject must abide by it. College students who start a business and enter the market is also a common market main body, not because of the identity of the college students, can do whatever they want, the consequences will be damage to the market order. In the process of entrepreneurship, college students must abide by many laws and regulations formulated by the state to regulate market transactions and competition activities of market subjects [4]. Therefore, entrepreneurship education in Colleges and universities must pay attention to the law related to entrepreneurship.

\section{PROBLEM ANALYSIS OF ENTREPRENEURIAL LAW EDUCATION}

\section{A. Paying not enough attention to the legal education of entrepreneurship}

At present, colleges and universities have not fully realized the realistic urgency of education. On the one hand, there are still doubts about whether it is necessary to strengthen the entrepreneurial law education. Some colleges and universities still treat the entrepreneurship education as an isolated education activity, without understanding the law education to entrepreneurship education is an important structure of the internal, ignoring the coordination between the factors of education and sustainable development. The research of education on entrepreneurship law is insufficient, and theory is the pioneer of practice. The construction of education on entrepreneurship law in colleges and universities must rely on the theoretical support and guidance of scientific system. The school, regional characteristics and experience of entrepreneurship education are insufficient. The influencing factors, industry characteristics and school characteristics of entrepreneurship education are not enough to echo the entrepreneurial law. The systematic and low-level nature of entrepreneurship law courses and the shortage of high-quality entrepreneurship law education teachers have led to the poor effect of the overall entrepreneurship law education.

\section{B. Not enough cross-integration}

Current scholars to study on the education of law is mostly aimed at law students, aim at raising the legal profession as the professional legal talents. While in modern times, in the "double creations" education of colleges and universities should pay attention to legal education, entrepreneurial talent objectively required higher legal literacy ability competence. University of professional education need to consider more each student's personality and learning needs, students on a particular subject or field of study process, will be integrated into other similar discipline knowledge. Professional education need to strengthen the response to the changing external environment. Training target, course system, teaching methods, assessment method also need to change to adapt to the era of knowledge economy in the definition of innovative talents. General education and professional education are the two most important components of education in universities. The former focuses on the needs of the student as a responsible person and citizen, while the latter gives the student some professional knowledge or vocational training. For general education, the interdisciplinary nature of entrepreneurial education is conducive to students' contact, understanding, absorption and transformation of knowledge in different subject areas. 


\section{MEASURES TO STRENGTHEN THE INTEGRATION OF LEGAL EDUCATION AND PROFESSIONAL EDUCATION.}

\section{A. Attaching Importance To The Entrepreneurial Law Education}

Colleges and universities are the specific implementers of education, which occupies a core position in education. Through the establishment of a strong legal atmosphere of entrepreneurship in colleges and universities, the improvement of education mechanism of entrepreneurship law in colleges and universities, and the promotion of industrialization of innovation results, colleges and universities turn the idea of entrepreneurship education into the real practice of university entrepreneurship education. Adhere to respect the law education general law and local conditions in combination [5]. On the one hand, combining with the experience of achievements and undertaking legal education in colleges and universities at home and abroad, combing with China's national conditions, and concluding the legal education embody Chinese characteristics of entrepreneurial ecosystem construction rule to provide solid theoretical support and practical principles for colleges and universities to strengthen the construction of entrepreneurship law education. Undertaking legal education in colleges and universities, on the other hand, are greatly influenced by the objective environment due to unbalanced regional economy in our country, so the entrepreneurship law education should break the restriction of the "only path" concept while respecting the general law, make full use of the regional characteristics, industry characteristics, advantages of colleges and universities, seek the convergence of interests among multiple parties, explore the education model that reflects the differences of university, region and industry characteristics according to local conditions [6].

\section{B. Establishing A Corresponding Curriculum System For Entrepreneurial Practice}

To construct a reasonable course system of entrepreneurship law, we should first analyze the risks faced by college students and their legal qualities. Legal consciousness and legal literacy are the necessary entrepreneurial consciousness and entrepreneurial accomplishment for college students, and legal knowledge and ability are the necessary knowledge and ability for college students to start a business [7]. The starting point of college students' entrepreneurship is the choice of the form of entrepreneurial organization, which is an essential link to obtain the qualification of legal operation. According to the individual proprietorship enterprise law, the partnership enterprise law and the company law of China, there are many differences in organizational forms, establishment conditions and legal liability. For the entrepreneurs with different starting points, reasonable selecting the appropriate forms of enterprises is of great significance to the entrepreneurial process, therefore, for entrepreneurship of college students should focus on understanding the laws and regulations, such as "the general civil law", "the company law", and its corresponding enterprise registration administration laws and regulations [8].

\section{Strengthening The Linkage Between Industry, University And Research}

The overall planning of entrepreneurship education in colleges and universities in our country is not perfected. In the process of internal operation, it presents the contradictory development situation of "multi sector participation and management, lack of joint force", "multi field scientific research results, lack of practice transformation", "multiplatform grants, long lasting help and insufficient support". In the construction and improvement of a good entrepreneurial ecosystem, with universities (Scientific Research Institute) as the core, set up an ecological knowledge system, enhance the system within the interaction mechanism of the various factors and promote the agglomeration of knowledge-based entrepreneurial full and free movement of the hatch "internal" and "external transformation" as an important channel, continue to promote industrial innovation around the knowledge-based entrepreneurial ecosystem, dominated by the government and the relevant incentive policy and management, become ensure orderly running the entire business ecosystem and maintain important foundation energy, increasing the local industrial upgrading and economic transformation [9]. Knowledge-based entrepreneurial ecosystem role has the characteristics of diversity, diversity of entrepreneurs, mainly including teachers in colleges and universities, research institutes of scientific research personnel, college student entrepreneurs and related industries. As knowledge-based entrepreneurial ecosystem with universities and research institutes for building new technology, new knowledge, so as a core business roles of teachers in colleges and universities and research institutes of scientific research personnel have what role does not have the general business ecosystem fully research and development of new technology and new knowledge and cultivating ability [10].

\section{Promoting education reform for all-around development}

Education should return to human development. Education should pay attention to the quality improvement of the educated, and pay attention to students' knowledge, ability and personality development. Therefore, education must be integrated into the personnel training system of colleges and universities, and innovation and entrepreneurship should be integrated into the whole process of personnel training [11]. Starting from the training needs of innovative and entrepreneurial talents in China, education should focus on constructing a three-level progressive curriculum system of "entrepreneurship general knowledge", "professional entrepreneurship", "entrepreneurship deepening". "Entrepreneurship general education" is a compulsory course for 2 to 4 credits of general education for all students in the university. "Professional entrepreneurship" course is a professional integration course for students of various majors. The course of "deepening entrepreneurship" is the course of deepening theory and practical experience of entrepreneurship for special groups [12]. 
Many professional teachers lack a deep understanding of the connotation of entrepreneurial education and have doubts about integrating entrepreneurial education into professional education. Therefore, universities should provide support in changing professional teachers' understanding of entrepreneurial education and encouraging professional teachers to explore entrepreneurial education teaching. [13]

\section{CONCLUSIONS}

Legal risks and legal problems are ubiquitous in the entrepreneurial process of college students. All of these legal risks affect the success rate of college students. Based on the analysis of college students' legal quality required of entrepreneurship, on the basis of reference to the concept of entrepreneurship education integration, cross fusion based on entrepreneurial qualities and legal quality, emphasis on college students' entrepreneurship need to strengthen the legal consciousness and conception, entrepreneurship requires legal risk prevention and self-advocacy and related legal capacity. Facing the new situation of economic and social development, science and engineering colleges need to actively explore the new situation of entrepreneurial education. To promote entrepreneurship law education reform, the crucial point is to strengthen the business the depth of the fusion between legal education and professional education, attach great importance to the business of legal education and legal professional course of entrepreneurship curriculum design and teaching, improve the legal professional endogenous support for entrepreneurship education teachers, establish a set of promote entrepreneurship law education and professional education integration mechanism. In a word, universities, government to society allround joint, each unique functions, promote each other and complement each other, the effect of legal education, doing pioneering work together effectively improve the quality of the college students entrepreneurship, entrepreneurial university students really benefit, the country's innovation entrepreneurship policy into effect.

\section{ACKNOWLEDGEMENTS}

This research was financially supported by National social science fund education general project "entrepreneurial law education research based on risk control in science and Engineering University", No. BIA170192.

\section{REFERENCES}

[1] Si Yang. Research on legal risks of entrepreneurship based on the perspective of legal education for university students [J]. Science mass (Science Education), 2017 (3): 128-128. (In Chinese)

[2] Zhang Shu Qin. A brief discussion on the perfection of legal education of College Students' entrepreneurship, [J]. Legal system and society, 2012 (6): 234-235. (In Chinese)

[3] Huang Zhaoxin, Huang Lijun, Song Zhaohui. Legal education for college students' Entrepreneurship: necessity, problems and suggestions [J]. Chinese higher education research, 2012 (11): 76-78. (In Chinese)

[4] Chen Xiao Hua. Lack and improvement of legal education in college students' entrepreneurship education, [J]. School party building and ideological education, 2016 (4): 84-85. (In Chinese)

[5] Yang Xiaohui. International comparison of the construction of entrepreneurship education ecosystem in Colleges and universities and the $[J]$. Study of Chinese higher education with Chinese characteristics, 2018 (1): 48-52. (In Chinese)

[6] Wang Debin. On the legal education of college students and the construction of their curriculum system $[\mathrm{J}]$. Heilongjiang higher education research, 2011 (1): 167-169. (In Chinese)

[7] Li Yanyan, Huang Zhaoxin. Research on the construction and operation mechanism of knowledge based entrepreneurial ecosystem [J]. Higher engineering education research, 2017 (6): 168-172. (In Chinese)

[8] Huang Zhaoxin, Luo Zhimin. The development strategy of entrepreneurship education in Colleges and universities from the perspective of pluralistic theory [J]. Education research, 2016 (11): 5864. (In Chinese)

[9] Xie Ren Hai. Research on legal protection mechanism of university students' Entrepreneurship from the perspective of risk theory $[\mathrm{J}]$. [J]. 2017, 11 (6): University Education Management. (In Chinese)

[10] Du Kang. What should he do? Also on University Entrepreneurship law education $[\mathrm{J}]$. Teaching and educating: Higher Education Forum, 2016 (18). (In Chinese)

[11] Li Wentao. Analysis of countermeasures for the construction of entrepreneurship education system in local engineering colleges and universities [J]. Jiangsu higher education, 2016 (1): 105-107. (In Chinese)

[12] Yan Mao Xin. Towards differences: the pattern of entrepreneurship education in higher education $[\mathrm{J}]$. Higher engineering education research, 2015 (2): 48-52. (In Chinese)

[13] Huang Zhaoxin, Wang Zhiqiang, on the integration of entrepreneurship education and professional education in Universities [J]. Education research, 2013 (12): 59-67. (In Chinese) 